\title{
of the World Meteorological Organization
}

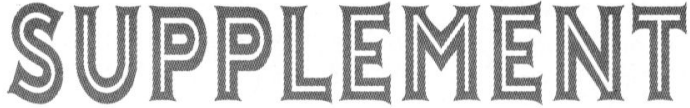

Distributed by the

American Meteorological Society

45 Beacon Street, Boston, MA 02108-3693

All prices listed below are quoted in U.S. dollars. Postage and handling is included in the price. (Availability and prices are subject to change without notice.) Orders and inquiries from residents of the U.S. and Canada should be directed to: American Meteorological Society, Attn WMO Publications Center, 45 Beacon Street, Boston, MA 02108, U.S.A Residents of all other countries should direct orders and inquiries to: World Meteorological Organization, Publications Sales Unit, Case Postale 2300, CH-1211 Geneva 2, Switzerland.

Remittance must accompany all orders; only after receipt of payment will the order be processed. Payment from Canadian clients must be made by a draft on a U.S. bank or by international money order. Checks or money orders should be made payable to the AMS in U.S. dollars.

WMO Bulletin-Quarterly Subscription+

\begin{tabular}{ccc}
$\begin{array}{c}\text { Number } \\
\text { of years }\end{array}$ & Surface mail & Airmail \\
\hline 1 & $\$ 60$ & $\$ 85$ \\
2 & $\$ 110$ & $\$ 150$ \\
3 & $\$ 145$ & $\$ 195$
\end{tabular}

+Subscriptions to WMO Bulletin are accepted on calendar year basis.

WMO 5-Composition of WMO-Quarterly Subscription

Number Surface mail
of years

$\begin{array}{cc}1 & \$ 125 \\ 2 & \$ 225 \\ 3 & \$ 300 \\ \text { Single issue } & \$ 35\end{array}$

${ }^{+}$Subscriptions to WMO 5 are accepted on calendar year basis.

\section{Atlases}

Climatic Atlas of Europe. Volume I: Maps of Mean Temperature and Precipitation-\$177

Climatic Atlas of South America. Volume I: Maps of Mean Temperature and Precipitation $-\$ 202$

Climatic Atlas of North and Central America. Volume I: Maps of Mean Temperature and Precipitation-\$177
International Cloud Atlas, Abridged Edition, 1956 \$ \$52

407 International Cloud Atlas

Vol. I, Manual on the Observation of Clouds and Other Meteors, 1975-\$52

Vol. II, Plates, 1987— $\$ 83$

659 Marine Cloud Album, 1987-\$25

\section{Basic Documents}

15 Basic Documents No. 1-(excluding Technical Regulations), 4th Edition, 1999—\$45

60 Basic Documents No. 3-Agreements and Working Arrangements With Other International Organizations, 1988— \$20 (with cover-\$35)

\section{Technical Regulations}

49 Technical Regulations-Basic Documents No. 2 (looseleaf; please specify if cover is needed)

Vol. I, General Meteorological Standards and Recommended Practices, 1988 edition- $\$ 51$

Vol. II, Meteorological Service for International Air Navigation, 1992 edition-\$35

Vol. III, Hydrology, 1988 edition-\$59

One cover-\$22, will accommodate volumes I, II, and III

\section{Weather Reporting, Stations, Data Processing, and Transmission}

9 Weather Reporting

Vol. A, Observing Stations: Basic Volume- $\$ 100$

Subscription to Supplement Service (Semi-annual):

Surface mail $\$ \$ 180$

Airmail $\$ 210$

Vol. B, Data Processing: Basic Volume-\$62; Cover-\$22 Subscription to Supplement Service (Semi-annual):

Surface mail $\$ 35$ Airmail $\$ 55$

Vol. C1, Catalogue of Meteorological Bulletins- $\$ 50$; Cover$\$ 22$

Subscription to Supplement Service (Bimonthly):

Surface mail \$135

Airmail $\$ 160$

Vol. C2, Transmissions Schedules- $\$ 72$

Subscription to Supplement Service (Bimonthly):

Surface mail $\$ 55$

Airmail $\$ 80$ 
Vol. D Information for Shipping: Basic Volume $-\$ 183$

Subscription to Supplement Service (Bimonthly):

$$
\begin{array}{ll}
\text { Surface mail } & \$ 110 \\
\text { Airmail } & \$ 185
\end{array}
$$

\section{Operation Manuals}

306 Manual on Codes

Vol. I International Meteorological Codes, 1995 edition

Part A-Alphanumeric-w/cover, $\$ 130$

Part B-Binary-w/cover, $\$ 70$

Vol. 11 Regional, 1998 edition-w/cover, $\$ 128$

386 Manual on the Global Telecommunication System, 1992 - \$136 (w/o cover), \$157 (w/cover)

Vol. I Global Aspects

Vol. II Regional Aspects

411 Information on Meteorological and Other Environmental

Satellites, 1994— $\$ 38$ w/o binder; $\$ 55$ w/binder

485 Manual on the Global Data Processing System (Vol. I and II, one cover), 1992-\$49; cover-\$17

Vol. I Global Aspects, 1977

Vol. II Regional Aspects, 1980

544 Manual on the Global Observing System (Vol. I and II, one cover), 1981-\$32; cover-\$17

558 Manual on Marine Meteorological Services, 1990 — \$35; cover $-\$ 17$

\section{Guides}

8 Guide to Meteorological Instruments and Observing Practices, 1996 - $\$ 155$

100 Guide to Climatological Practices, 2nd edition, 1983 — \$44

134 Guide to Agricultural Meteorological Practices, 2nd edition, $1981-\$ 34$

168 Guide to Hydrological Practices, 1994-\$105

305 Guide on the Global Data Processing System, 1993—\$58 w/o cover; $\$ 75$ w/cover

471 Guide to Marine Meteorological Services, 3rd edition, 1982 $\$ 55$

488 Guide on the Global Observing System, 1989—\$47

623 Guide to the IGOSS Data Processing and Services System, $1983-\$ 20$

634 Guidelines for Computerized Data Processing in Operational Hydrology and Land and Water Management, 1985—\$39

636 Guide on the Automation of Data Processing Centers, 1998$\$ 55$

702 WMO Guide to Wave Analysis and Forecasting, 1998 — \$69

731 Guide to Meteorological Observation and Information Distribution Systems at Aerodromes, 1990—\$29

732 Guide to Practices for Meteorological Offices Serving Aviation, $1990-\$ 31$

781 Guide to Applications of Marine Climatology, 1994—\$29 w/o cover; $\$ 46$ w/cover

788 Guide on the WWW Data Management, 1993-\$27

834 Guide to the Public Weather Services Practices, 1999, 2nd edition-\$45

842 Guide to the Provision of Meteorological Service for International Helicopter Operations, 1997-\$20
904 Guide on Aeronautical Meteorological Services Cost Recovery $-\$ 21$

\section{Training Manuals}

240 Compendium of Training Facilities for Meteorology and Operational Hydrology, 1996-\$65

258 Guidelines for Education and Training of Personnel in Meteorology and Operational Hydrology, 3rd edition, 1984$\$ 44$

266 Compendium of Lecture Notes for Training Class IV Meteorological Personnel:

Vol. I, Earth Science, 1970 - $\$ 28$

Vol. II, Meteorology, 2nd edition, 1984-\$52

364 Compendium of Meteorology for use by Class I and II Meteorological Personnel

Vol. II: Part 1: General Hydrology, 1977— \$20

Part 3: Marine Meteorology, 1979—\$21

Part 4: Tropical Meteorology, 1979—\$45

Part 5: Hydrometeorology, 1985-\$24

$\$ 31$

Part 6: Air Chem. and Air Pollut. Meteorol., 1985-

434 Compendium of Lecture Notes in Marine Meteorology for Class III and Class IV Personnel, 1991— \$42

593 Lecture Notes for Training Class IV Agricultural Meteorological Personnel, 1982-\$24

622 Compendium of Lecture Notes on Meteorological Instruments for Training Class III and Class IV Meteorological Personnel, 1986

Vol. I: Part 1: Meteorological Instruments;

Part 2: Meteorological Instrument Maintenance Workshops, Calibration Laboratories and Routines-\$44

Vol. II: Part 3: Basic Electronics for the Meteorologist- $\$ 42$

669 Workbook on Numerical Weather Prediction for the Tropics for the Training of Class I and Class II Meteorological Personnel, $1986-\$ 44$

726 Compendium of Lecture Notes in Climatology for Class III and Class IV Personnel, 1992—\$39

\section{Operational Hydrology Reports}

332 Manual for Estimation of Probable Maximum Precipitation, O.H.R. 1; 1986-\$38

341 Benefit and Cost Analysis of Hydrological Forecasts. A Stateof-the-Art Report, O.H.R. 3; 1973-\$20

429 Intercomparison of Conceptual Models Used in Operational Hydrological Forecasting, O.H.R. No. 7; 1975—\$33

433 Hydrological Network Design and Information Transfer. Proceedings of the International Seminar, Newcastle upon Tyne, U.K., August 1974, O.H.R. 8; 1976—\$41

461 Casebook of Examples of Organization and Operation of Hydrological Services, O.H.R. 9; 1977— \$32

513 Applications of Remote Sensing to Hydrology, O.H.R. 12; $1979-\$ 20$

519 Manual on Stream Gauging (2-volume set in one binder), O.H.R. 13; 1980-\$66

559 Hydrological Data Transmission, O.H.R. 14; 1981— $\$ 20$ 
560 Selection of Distribution Types for Extremes of Precipitation, O.H.R. $15 ; 1981-\$ 20$

561 Measurement of River Sediments, O.H.R. 16; 1981— \$20

576 Case Studies of National Hydrological Data Banks (Planning, Development and Organization), O.H.R. 17; 1981-\$20

577 Flash Flood Forecasting, O.H.R. 18; 1981-\$20

580 Concepts and Techniques in Hydrological Network Design, O.H.R. 19; 1982-\$20

587 Long-Range Water-Supply Forecasting, O.H.R. 20; 1982— $\$ 20$

589 Methods of Correction for Systematic Error in Point Precipitation Measurement for Operational Use, O.H.R. 21; 1982 - \$20

635 Casebook on Operational Assessment of Areal Evaporation, O.H.R. 22; 1985- $\$ 28$

646 Intercomparison of Models of Snowmelt Runoff, O.H.R. 23; $1986-\$ 56$

650 Level and Discharge Measurement Under Difficult Conditions, O.H.R. 24; 1986-\$20

655 Tropical Hydrology, O.H.R. 25; 1987— \$20

658 Methods of Measurement and Estimation of Discharges at Hydraulic Structures, O.H.R. 26; 1986-\$20

680 Manual on Water Quality Monitoring, O.H.R. 27, 1988— \$27

683 Hydrological Information Referral Service-INFOHYDRO Manual, O.H.R. 28, $1994 \$ \$ 137$

686 Manual on Operational Methods for Measurements of Sediment Transport, O.H.R. 29; 1989-\$22

704 Hydrological Aspects of Combined Effects on Storm Surges and Heavy Rainfall on River Flow, O.H.R. 30; 1988 - \$20

705 Management of Groundwater Observation Programmes, O.H.R $31-\$ 23$

717 Cost-Benefit Assessment Techniques and User Requirements for Hydrological Data, O.H.R. No. 32-\$26

718 Statistical Distributions for Flood Frequency Analysis, O.H.R., No. $33-\$ 22$

740 Hydrological Models for Water-Resources Systems Design and Operation, O.H.R., No. $34-\$ 23$

749 Snow Cover Measurements and Areal Assessment of Precipitation and Soil Moisture, O.H.R. 35, 1991—\$45

754 Hydrological Aspects of Accidental Pollution of Water Bodies, O.H.R. 37, 1992- $\$ 40$

773 Remote Sensing for Hydrology Process Prospects, O.H.R. 36, $1992-\$ 25$

779 Simulated Real-time Intercomparison of Hydrological Models, O.H.R. 38, 1992- $\$ 41$

803 Land Surface Processes in Large-Scale Hydrology, O.H.R. 40$\$ 25$

804 Applications of Remote Sensing by Satellite, Radar and Other Methods of Hydrology, O.H.R. 39-\$21

806 An Overview of Selected Techniques for Analysing Surface Water Data Networks, O.H.R. 41-\$20

885 Areal Modelling in Hydrology Using Remote Sensing, O.H.R. $44-\$ 20$

886 Contaminants in Rivers \& Streams, O.H.R. 45-\$20

\section{Special Environment Reports}

455 The Quantitative Evaluation of the Risk of Disaster from Tropical Cyclones, S.E.R. No. 8; 1976-\$60

496 Systems of Evaluating and Predicting the Effects of Weather and Climate on Wildland Fires, S.E.R. 11; 1978—\$18
647 Lectures Presented at the WMO Technical Conference on Observation and Measurements of Atmospheric Contaminants (TECOMAC), S.E.R. 16;1985—\$72

\section{Marine Science Affairs}

750 Guide to Moored Buoys and Other Ocean Data Acquisitions Systems, M.S.A. No. 16; 1990—\$20

\section{Technical Notes}

243 Meteorology and Grain Storage, T.N. 101; 1990 ed.-\$21

319 Dispersion and Forecasting of Air Pollution, T.N. 121; 1972$\$ 29$

415 On the Statistical Analysis of Series of Observations, T.N. 143; $1990-\$ 57$

487 Techniques of Frost Prediction and Methods of Frost and Cold Protection, T.N. 157; 1978-\$45

495 Handbook of Meteorological Forecasting for Soaring Flight, T.N. 158; 1993-\$29

498 Soya Bean and Weather, T.N. 160; 1978 - \$29

531 Quantitative Meteorological Data from Satellites, T.N. 166; 1979 - \$29

562 Weather and Airborne Organisms, T.N. 173; 1980 - \$21

620 Weather-Based Mathematical Models for Estimating Development and Ripening of Crops, T.N. 180; 1983-\$21

625 Use of Radar in Meteorology, T.N. 181; 1985-\$35

629 Analysis of Data from International Experiments on Lucerne, T.N. 182; 1985- $\$ 26$

633 Land Use and Agro-System Management Under Severe Climatic Conditions, T.N. 184; 1985-\$30

641 Meteorological Observations using NAVAID Methods, T.N. $185 ; 1985-\$ 20$

662 Land Management in Arid and Semi-Arid Areas, T.N. 186; $1989-\$ 35$

665 Guidance Material on the Calculation of Climatic Parameters Used for Building Purposes, T.N. 187; 1992-\$32

672 Applications of Meteorology to Atmospheric Pollution Problems, T.N. 188; 1987-\$20

679 Contribution of Satellite Data and Service to WMO Programs in the Next Ten Years, T.N. 189; 1987— \$39

684 Weather and Climate and Animal Performance, T.N. 190; $1988-\$ 31$

685 Animal Health and Production at Extremes of Weather, T.N. $191 ; 1988-\$ 34$

687 Agrometeorological Aspects of Operational Crop Protection, T.N. 192; 1988- $\$ 30$

703 Agroclimatology of the Sugar Cane Crop, T.N. 193; 1989—\$23

759 Measurement of Air Temperature and Humidity, T.N. 194; $1991-\$ 20$

770 Methods of Interpreting Numerical Weather Prediction Output for Aeronautical Meteorology, T.N. 195; 1999—\$45

802 Climate Variability, Agriculture, and Forestry, T.N. 196-\$35

839 Agrometeorology of Grass and Grasslands for Middle Latitudes, T.N. 197; 1997—\$20

840 The Effect of Temperature on the Citrus Crop, T.N. 198; 1997 - 20

841 Climate Variability, Agriculture and Forestry: An Update, T.N. 199; 1997— $\$ 23$ 


\section{World Weather Watch Planning Reports}

553 Conversion of Grid-Point Data into Meteorological Maps with a Mini-Computer System, WWW 37, 1980-\$20

621 Very Short-range Forecasting Observations, Methods, and Systems, WWW 38, 1983-\$23

\section{World Weather Watch Status Reports}

714 World Weather Watch-14th Status Report on Implementation, 1989 - \$29

753 World Weather Watch - 15th Status Report on Implementation, 1992 - \$33

790 World Weather Watch - 16th Status Report on Implementation, $1994-\$ 39$

823 World Weather Watch-17th Status Report on Implementation, 1996 - \$37

855 World Weather Watch - 18th Status Report on Implementation, $1997-\$ 31$

894 World Weather Watch - 19th Status Report on Implementation, $1999-\$ 45$

\section{General Reference Publications}

2 Meteorological Services of the World, '94 $\$ 47$ w/o binder; $\$ 64$ w/binder

5 Composition of the World Meteorological Organization Annual Subscription- $\$ 110$

47 International List of Selected, Supplementary and Auxiliary Ships, 1998-\$65

117 Climatological Normals (CLINO) for CLIMAT and CLIMAT SHIP stations for the period 1931-1960, 1971-\$45

174 Catalogue of Meteorological Data for Research: Part IV: Sources of Additional Data Needed for Research on Climatic Change, 1979-\$25

259 WMO Sea-Ice Nomenclature, 1970 (Vol. I and III, one cover)$\$ 39$

Vol. I, Terminology and Codes, 1970

Vol. III, International System of Sea Ice Symbols, 1970

634 Guidelines for Comprehensive Data Processing in Operational Hydrology and Land Water Management, 1985-\$39

847 Climatological Normals (CLINO) for the Period 1961-1990, $1996-\$ 129$

\section{Publications of General Interest}

182 International Meteorological Vocabulary, 1992—\$95

309 Radiation Processes in the Atmosphere, 1972 - \$65

385 International Glossary of Hydrology, 1992-\$67

411 Information on Meteorological and Other Environmental Satellites, 1994— $\$ 38$ w/o binder; $\$ 55$ w/binder

523 The Atmosphere Boundary Layer, 1979—\$29

528 WWW-WMO Tropical Cyclone Project-Sub-Project No. 6: Operational Techniques for Forecasting Tropical Cyclone Intensity and Movement, 1979-\$30

542 Climatic Changes and Their Effects on the Biosphere, 1980$\$ 39$
Sea-Ice Information Services in the World, 2000— $\$ 55$ Monsoons, 1986-\$48

Tropical Cyclone Operational Plan for the Southwest Indian Ocean, 1990; \$27—w/o binder; \$44—w/binder

Meteorology Aids Food Production, 1985-\$20

Meteorology and Public Safety, $1984 \$ \$ 20$

Proceedings of the Technical Conference on Urban Climatology and Its Applications with Special Regard to Tropical Areas (Mexico D.F., 26-30 November 1984), 1986-\$58

Climate Variations, Drought, and Desertification, 1985-\$20

Report of the International Conference on the Assessment of the Role of Carbon Dioxide and of Other Greenhouse Gases in Climate Variations and Associated Impacts, 1986-\$20

Meteorology and the Media, 1987—\$20

Dispersion Processes in Large Scale Weather Prediction-6th IMO Lecture, 1989—\$92

Mesometeorology and Short-Range Forecasting, 1990 — \$20

Meteorology in the Service of Aviation by J. Kastelein, 1988$\$ 20$

The Bulletin Interviews, 1988- $\$ 30$

World Weather Watch 25th Anniversary Brochure, 1989—\$20

Mesoscale Forecasting and Its Applications: Lectures Presented at the 40th Session of EC, 1989— \$27

A Historical Review of WMO, 1990—\$95

IGOSS Plan and Implementation Report, 1989—\$20

The WMO Achievement: 40 Years in the Service of International Meteorology and Hydrology, 1990—\$20

Economic and Social Benefits of Meteorological and Hydrological Services, 1990—\$55

Meteorological and Hydrological Risk Assessment and Disaster Reduction: Lectures Presented at the 42nd Session of the Executive Council, 1990-\$20

WMO and Global Warming, 1990 - \$20

The Role of WMO in the International Decade for Natural Disaster Reduction, 1990-\$20

Climate Change: World Leaders' Viewpoints, 1991—\$20

Guide to Moored Buoys and Other Ocean Data Acquisitions Systems, 1990-\$20

Protecting the Atmosphere, Oceans, and Water Resources: Sustainable Use of Natural Resources, 1992 (WMO and UNCED)— $\$ 20$

The World Weather Watch Programme 1992-2001-Third WMO Long-Term Plan, 1992—\$20

The World Climate Programme 1992-2001-Third WMO Long-Term Plan, Part II, Volume 2, 1992 — \$20

The Atmospheric Research and Environment Programme 1992-2001-Third WMO Long-Term Plan, Part II, Volume 3, $1992-\$ 20$

64 The Applications of Meteorology Programme 1992-2001Third WMO Long-Term Plan, Part II, Volume 3, 1992—\$20

65 The Hydrology and Water Resources Programme 1992-2001Third WMO Long-Term Plan, Part II, Volume 5, 1992—\$20 The Education and Training Programme 1992-2001-Third AMO Long-Term Plan, Part II, Volume 6, 1992 - \$20

The Technical Co-operation Programme 1992-2001-Third WMO Long-Term Plan, Part II, Volume 7, 1992-\$20

8 The WMO Long-Term Plan, Overall Policy and Strategy 19922001-Third WMO Long-Term Plan, Part I, 1992— \$25

Meteorology and Hydrology for Sustainable Development, $1992-\$ 20$ 
Third Long-Term Plan, 1992-2001: Summary of Objectives, Policies, and Strategy, 1992-\$21

777 The Global Climate Observing System (GCOS): Responding to the Need for Climate Observations, 1992-\$20

778 WMO and the Ozone Issue, 1992 — \$20

782 Aerodome Reports and Forecasts: A User's Handbook, 1992$\$ 21$

786 Meteorology and the Transfer of Technology, 1993-\$21

796 Observing the World's Environment: Weather, Climate and Water, 1994-\$20

799 A Decade Against Natural Disasters, 1994—\$20

801 Assessing a Precious Resource ... Water, 1994-\$20

809 WMO Statement on the Status of the Global Climate in 1993 $\$ 20$

814 WMO and the Protection of Climate, 1994-\$20

816 On the Front Line: Public Weather Services, 1994-\$20

817 Beyond the Earth Summit-WMO and the Follow-up to UNCED, 1995-\$20

819 The Global Climate System Review (1991-1993), 1995-\$20

821 A Response to the Weather and Climate Challenge: The WWW, $1995-\$ 20$

826 WMO Statement on the Status of the Global Climate in 1994 (1995)-\$20

828

830

The Changing Ozone Layer, 1995-\$20

831 2005-Fourth WMO Long-Term Plan, Part I, 1996-\$25 Objectives, Policies, and Strategy, 1996-\$20

832 Climate Information and Prediction Services, 1995-\$20

835 Weather and Sports, 1996-\$20

837 Exchanging Meteorological Data. Guidelines on Relationships in Commercial Meteorological Activities-WMO Policy and Practice, 1996-\$21

WMO Statement on the Status of the Global Climate in 1995 $1996-\$ 20$

843 Climate and Human Health, 1996-\$20

844 Climate and Urban Development, 1996-\$20

848 WMO and Climate Change, 1996-\$20

849 Food Security: The Climate Factor, 1996-\$20

853 Weather and Water in Cities, 1997-\$20

856 The Global Climate System Review (1994-1996) — \$30

857 The World's Water: Is There Enough?, 1997—\$20

858 WMO Statement on the Status of the Global Climate in 1996 $\$ 20$

861 Weather \& the Media: A Press Relations Guide, 1997-\$20

862 GHOST — Global Hierarchical Observing Strategy, 1997_\$20

863 Mobilizing Resources for Technical Cooperation, 1997-\$20

864 Stepping Forward-Implementation of the WMO CLIPS Project, 1997-\$20

865 The Bulletin Interviews-1989-1997— \$95

869 Climate, Drought and Desertification, 1997—\$20

871 Weather, Oceans and Human Activity, 1997-\$20

872 The Global Observing System of the World Weather Watch, 1997 - $\$ 20$

873 Integrated Programme on Hydrometeorology and Monitoring of Environment in CASPAS, 1997-\$20

876 WHYCOS: World Hydrological Cycle Observing System, $1998-\$ 20$

877 WMO Statement on the Status of the Global Climate in 1997, $1998-\$ 20$

878 WMO and the World's Water, 1998_\$20
897

898

906

909

913 WMO Statement on the Status of the Global Climate in 1999, $2000-\$ 20$

914 Proceedings of the WMO/UNESCO Sub-Forum on Science and Technology in Support of Natural Disaster Reduction, 1999_ $\$ 75$

\section{Commission, Congress, Executive, and Annual Reports}

508 Resolutions of Congress and Exec. Committee, 1985-\$50

614 Scientific Lectures Presented at the 9th World Meteorological Congress, Geneva 1983; 1985-\$25

649 Scientific Lectures Presented at the 36th Session of the WMO Executive Committee, $1984-\$ 20$

682 WMO Executive Council 39th Session-Abridged Final Report, (1987); 1988-\$28

689 Annual Report of the World Meteorological Organization, (1987); 1988-\$48

698 Tenth World Meteorological Congress (1987)_Proceedings, $1988-\$ 29$

699 Commission for Basic Systems-Abridged Final Report of the Ninth Session (1988), 1988-\$58

723 Forty-First Session of the Executive Council (1989): Abridged Report with Resolutions-\$32

734 Annual Report of WMO (1989) 1990-\$26

743 Commission for Atmospheric Sciences-Abridged Final Report of the Tenth Session (1990), 1991-\$26

746 Annual Report of WMO (1990), 1991—\$27

751 Commission for Basic Systems - Abridged Final Report of the Extraordinary Session (1990), 1991— $\$ 48$

756 Eleventh World Meteorological Congress (1991)_Abridged Report with Resolutions, 1991—\$31

757 Eleventh World Congress (1991)_Proceedings, 1991— \$35

758 Forty-Third Session of the Executive Council (1991) Abridged Report with Resolutions, 1991-\$25

771 Special Topics on Climate-Lectures Presented at the 42nd Session of the WMO Executive Council (1990), 1993-\$20 Annual Report of WMO (1991), 1992—\$33

775 Commission for Agricultural Meteorology-Abridged Final Report of the Tenth Session (1991), 1992 — \$25

780 Forty-fourth Session of the Executive Council (1992) - \$29

783 Regional Association II (Asia)_Abridged Final Report of the Tenth Session (1992), 1993—\$37 
784 Commission for Basic Systems-Abridged Final Report of the Tenth Session (1992), 1993—\$45

785 Proceedings of the Technical Conference on Tropical Aeronautical Meteorology (TECTAM-92), 1993-\$73

787 Annual Report of the WMO, 1992—\$33

789 Commission for Hydrology-Abridged Final Report of the Ninth Session (1993), 1993-\$31

791 Commission for Climatology-Abridged Final Report of the Eleventh Session, 1993-\$25

792 Commission for Marine Meteorology - Abridged Final Report of the Eleventh Session, 1993-\$39

793 Regional Association IV (North and Central America) Abridged Final Report of the Eleventh Session, 1993 — \$25

794 Forty-Fifth Session of the Executive Council-Abridged Report with Resolutions, 1993-\$33

795 Scientific lectures at CG-11, 1993-\$21

798 Climate Change Issues-Lectures Presented at the 44th Session of the WMO Executive Council (1992), 1994—\$20

800 Annual Report of the World Meteorological Organization, $1993-\$ 31$

805 Lectures Presented at the Forty-Fifth Session of the WMO Executive Council (1993), 1994—\$21

807 Commission for Instruments and Methods of ObservationAbridged Final Report of the 11th Session, 1994 \$ \$27

808 Commission for Atmospheric Sciences-Abridged Final Report of the 11th Session, 1994-\$23

815 Commission for Basic Systems-Abridged Final Report of the Extraordinary Session, 1994—\$37

818 Commission for Aeronautical Meteorology_Abridged Final Report of the 10th Session, 1994—\$25

822 Lectures Presented at the Forty-Sixth Session of the WMO Executive Council (1994), 1995—\$20

824 Annual Report of the World Meteorological Organization, $1994-\$ 27$

825 Commission for Agricultural Meteorology—Abridged Final Report of the 11 th Session, 1995-\$27

827 Twelfth World Meteorological Congress (1995)—Abridged Final Report with Resolutions-\$37

829 Forty-seventh Session of the Executive Council (1995) Abridged Final Report with Resolutions- $\$ 20$

836 Annual Report of the World Meteorological Organization, $1996-\$ 27$

845 Scientific Lectures Presented at the 12th World Meteorological Congress - 1995; 1996-\$43

846 Forty-Eighth Session of the Executive Council (1996)Abridged Final Report with Resolutions, 1996-\$39

852 Commission for Hydrology-Abridged Final Report of the 10th Session, 1997-\$23

854 Commission for Basic Systems-Abridged Final Report of the 11th Session, 1997-\$33

859 Annual Report of the World Meteorological Organization, $1996-\$ 27$

860 Commission for Marine Meteorology-Abridged Final Report of the 12th Session, 1997— $\$ 43$

866 Scientific Lectures Presented at EC XLVIII (1996), 1997— \$35

867 Forty-Ninth Session of the Executive Council (1997)Abridged Final Report with Resolutions, 1997— \$41

870 Commission for Climatology-Abridged Final Report of the 12th Session (1997), 1997— \$29

875 Annual Report of the World Meteorological Organization (1997), 1998-\$27
879 Commission for Atmospheric Sciences-Abridged Final Report of the 12th Session (1998), 1998-\$23

881 Commission for Instruments \& Methods of ObservationAbridged Final Report of the 12th Session, 1997- \$33

883 Fiftieth Session of the Executive Council, 1998-Abridged Final Report with Resolutions, 1998—\$53

893 Commission for Basic Systems-Abridged Final Report of the Extraordinary Session, 1998-\$71

895 Annual Report of the WMO, 1998-\$27

899 Commission for Aeronautical Meteorology—Abridged Final Report of the 11th Session, 1999-\$35

902 13th World Meteorological Congress-Abridged Final Report with Resolutions- $\$ 61$

903 51st Session of the Executive Council-Abridged Final Report with Resolutions-\$27

900 Commission for Agricultural Meteorology-Abridged Final Report of the Twelfth Session (1999), 1999—\$45

907 Annual Report of the World Meteorological Organization 1999, 2000 - $\$ 27$

910 Lectures Presented at the Forty-Ninth Session of the WMO Executive Council, 2000-\$21

911 Lectures Presented at the Fiftieth Session of the WMO Executive Council, 2000-\$21

\section{Reports of Sessions of Regional Associations}

678 Regional Association I (Africa) - Abridged Final Report of the Ninth Session (1986), 1987—\$37

711 Regional Association II (Asia) 9th Session-Abridged Final Report, 1989— \$38

719 Regional Association IV (North and Central America)Abridged Final Report of the Tenth Session- $\$ 31$

730 Regional Association V (Southwest Pacific)—Abridged Final Report of the Tenth Session-\$26

736 Regional Association VI (Europe) - Abridged Final Report of the Tenth Session, 1990—\$20

755 Regional Association I (Africa) - Abridged Final Report of the Tenth Session (1990), 1991— \$38

783 Regional Association II (Asia)-Abridged Final Report of the Tenth Session, 1992— \$37

793 Regional Association IV (North and Central America)Abridged Final Report of the 11th Session, 1993-\$25

797 Regional Association III (South America) - Abridged Final Report of the 11th Session (1993), 1994-\$23

811 Regional Association V (South-West Pacific) - Abridged Final Report of the 11th Session, 1994—\$25

812 Regional Association VI (Europe)-Abridged Final Report of the 11th Session (1994) - $\$ 31$

820 Regional Association I (Africa) - Abridged Final Report of the 11th Session, 1994-\$29

851 Regional Association II (Asia) - Abridged Final Report of the 11th Session, 1996-\$35

868 Regional Association IV (North and Central America)Abridged Final Report of the 12th Session, 1997-\$25

874 Regional Association III (South America) - Abridged Final Report of the 12th Session, 1997-\$21

882 Regional Association VI (Europe) - Abridged Final Report with Resolutions, 1998-\$20 
888 Regional Association V (South-West Pacific), 1998— \$20

890 Regional Association V (South-West Pacific)—Abridged Final Report with Resolutions, 1998—\$39

891 Regional Association I (Africa) - Abridged Final Report with Resolutions, 1998 - \$55

\section{WMO Cloud Sheet, 1986}

The dimensions of the WMO Cloud Sheet are $39 \times 83 \mathrm{~cm}$. This popular sheet is printed on glossy paper and can be mounted on a hard backing. Thirty eight color photographs were selected to assist not only the marine observer, but also as a general reference for all professional or amateur meteorological observers.

\section{QUANTITY}

PRICE PER CLOUD SHEET

(Prices do not include shipping and handling)

$\begin{array}{rr}1-10 & \$ 5.00 \\ 11-30 & \$ 4.00 \\ 31-50 & \$ 3.00 \\ 51-100 & \$ 2.75 \\ 101-500 & \$ 2.50 \\ 501-1000 & \$ 2.25 \\ 1000+ & \$ 2.00\end{array}$

Shipping and handling charges: $1-10-\$ 5 /$ sheet; $11-100-\$ 10 / 10$ sheets. Contact AMS for shipping and handling costs for orders over 100 sheets.

Questions concerning WMO publications should be addressed to: Beth Farley, AMS, 45 Beacon Street, Boston, MA 02108-3693; (617) 227-2426, x214. All orders for WMO Publications are for United States and Canada only. 


\section{Journal of the Atmospheric Sciences}

Vol. 58, No. 9, 1 May 2001

\section{ARTICLES}

Observed Dynamics of Coastal Flow at Cape Mendocino during Coastal Waves 1996 . Linda Ström, Michael Tuernström, and David P. Rogers

Coupling Cloud Processes with the Large-Scale Dynamics Using the Cloud-Resolving Convection Parameterization (CRCP) ................................................................................. WOJCIECH W. GRABOWSKI Application of the Zhang-Gal-Chen Single-Doppler Velocity Retrieval to a Deep Convective Storm ................ Steven Lazarus, Alan Shapiro, and Kelvin Droegemeier Large-Eddy Simulations of the 26 November 1991 FIRE II Cirrus Case William Y. Y. Cheng, Ting Wu, and William R. Cotton 1017-1034

Rossby Waves in Zonally Opposing Mean Flow: Behavior in Northwest Pacific Summer Monsoon Hung-Chi Kuo, Jen-Her Chen, R. T. Williams, and C.-P. Chang 1035-1050

Three-Dimensional Effects in High-Drag-State Flows over Long Ridges

Craig C. Epifanio and Dale R. Durran 1051-1065

Finite-Time Evolution of Small Perturbations Superposed on a Chaotic Solution: Experiment with an Idealized Barotropic Model ………………………………………………….. Shozo YAmane And Shigeo Yoden 1066-1078 Two Distinct Regimes in the Kinematic and Thermodynamic Structure of the Hurricane Eye and Eyewall ......... ... James P. Kossin AND MatThew D. Eastin 1079-1090

Coherent Scattering of Microwaves by Particles: Evidence from Clouds and Smoke

J. S. Erkelens, V. K. C. Venema, H. W. J. Russchenberg, and L. P. Ligthart 1091-1102

A Comparison of Total Column Ozone Values Derived from the Global Ozone Monitoring Experiment (GOME), the Tiros Operational Vertical Sounder (TOVS), and the Total Ozone Mapping Spectrometer (TOMS) Gary K. Corlett and Paul S. Monks 1103-1116

Systematic Biases in the Microphysics and Thermodynamics of Numerical Models That Ignore Subgrid-Scale Variability VINCENT E. LARSON,

Robert Wood, Paul R. Field, Jean-Christophe Golaz, Thomas H. Vonder Haar, and William R. Cotton 1117-1128 Excitation of the 10-Day and 16-Day Waves Hyeong-Bin Cheong and Ryuji Kimura 1129-1145 Instability of Neutral Eady Waves and Orography ..................................... Maurizio Fantini And Silvio Davolio 1146-1154 Long-Term Behavior of Cloud Systems in TOGA COARE and Their Interactions with Radiative and Surface Processes. Part III: Effects on the Energy Budget and SST Xiaoding Wu and Mitchell W. MoncriefF 1155-1168

New Third-Order Moments for the Convective Boundary Layer

\section{NOTES AND CORRESPONDENCE}

Comments on Frictional Dissipation in a Precipitating Atmosphere

Nilton O. RenNó 1173-1177 Reply Olivier Pauluis, V. Balaji, and Isaac M. Held 1178-1179 


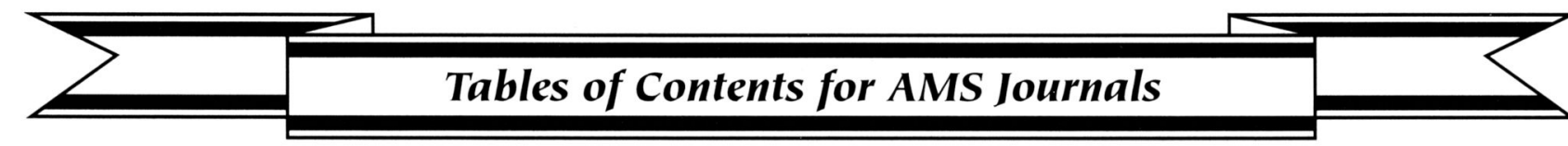

\section{Journal of the Atmospheric Sciences}

Vol. 58, No.10, 15 May 2001

\section{ARTICLES}

Microphysical Parameterization of Arctic Diamond Dust, Ice Fog, and Thin Stratus for Climate Models

ERic Girard and Jean-Pierre Blanchet 1181-1198

Simulation of Arctic Diamond Dust, Ice Fog, and Thin Stratus Using an Explicit Aerosol-Cloud-Radiation Model

.. ERIC Girard and Jean-Pierre Blanchet 1199-1221

Kinematic and Thermodynamic Study of a Shallow Hailstorm Sampled by the McGill Bistatic Multiple-

Doppler Radar Network

Alain Protat, Isztar Zawadzki, and Alain Caya 1222-1248

Numerical Modeling of Gravity Wave Generation by Deep Tropical Convection .....

Todd P. Lane, Michael J. Reeder, and Terry L. Clark 1249-1274

A Lidar and Backscatter Sonde Measurement Campaign at Table Mountain During February-March 1997:

Observations of Cirrus Clouds

G. Beyerle, M. R. Gross,

D. A. Haner, N. T. Kuome, I. S. McDermid, T. J. McGee, J. M. Rosen, H. J. Schäfer, And O. Schrems $1275-1287$

Long-Term Observations of the Dynamics of the Continental Planetary Boundary Layer

Chuixiang Yi, Kenneth J. Davis, Bradford W. Berger, and Peter S. Bakwin 1288-1299

Radiative Influence of Antarctica on the Polar-Night Vortex .....

Gene L. Francis and Murry L. Salby 1300-1309

Topographic Effects on Barotropic Vortex Motion: No Mean Flow

Hung-Chi Kuo, R. T. Williams, Jen-Her Chen, and Yi-Liang Chen 1310-1327

\section{NOTES AND CORRESPONDENCE}

Comments on "A Sensitivity Study of Radiative-Convective Equilibrium in the Tropics with a Convection-

Resolving Model"

W.-K. TaO, C.-L. ShIE, AND J. Simpson 1328-1333

Reply

Kuan-Man Xu and David A. Randall 1334-1338 


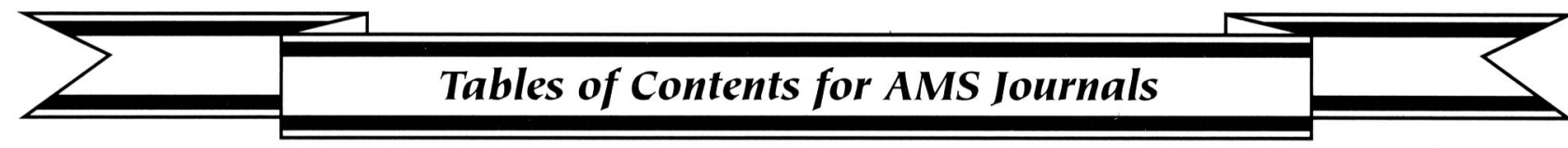

\section{Journal of Applied Meteorology}

Vol. 40, No. 5, May 2001

\section{ARTICLES}

A Dynamic Probability Model of Hurricane Winds in Coastal Counties of the United States

Thomas JagGer, James B. Elsner, And Xufeng Niu

Modification of an Operational Dispersion Model for Urban Applications

Peter de Haan, Mathias W. Rotach, and Maja Werfeli

Simulations of Mesoscale Circulations in the Center of the Iberian Peninsula for Thermal Low Pressure Conditions. Part I: Evaluation of the Topography Vorticity-Mode Mesoscale Model

.. Fernando Martin, Sylvia N. Crespi, and Magdalena Palacios

Simulations of Mesoscale Circulations in the Center of the Iberian Penisula for Thermal Low Pressure Conditions. Part II: Air-Parcel Transport Patterns

Fernando Martin, Magdalena Palacios, and Sylvia N. CRespi

Calculation of Area-Averaged Fluxes: Application to BOREAS

. Larry Mahrt, Dean Vickers, Jielun Sun, and J. Harry McCaughey

A Cooperative Atmosphere-Surface Exchange Study (CASES) Dataset for Analyzing and Parameterizing the Effects of Land Surface Heterogeneity on Area-Averaged Surface Heat Fluxes

DAVID N. YATES, FEI CHEN, Margaret A. LeMone, Russell Qualls, Steven P. Oncley, Robert L. Grossman, and Edward A. Brandes

Sampling Errors of SSM/I and TRMM Rainfall Averages: Comparison with Error Estimates from Surface Data and a Simple Model

Thomas L. Bell, Prasun K. Kundu, and Christian D. Kummerow 


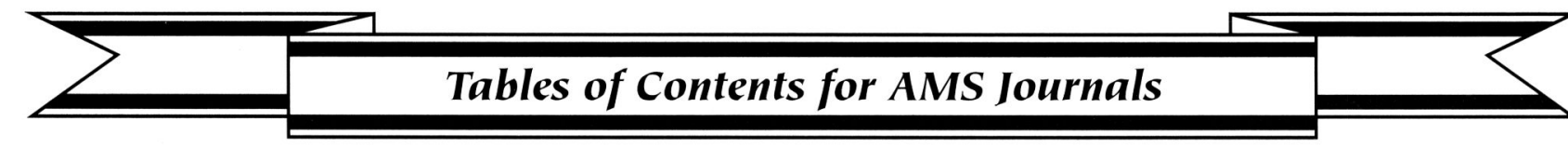

\section{Journal of Atmospheric and Oceanic Technology}

Vol. 18, No. 5, May 2001

\section{ARTICLES}

A Continuous-Flow Diffusion Chamber for Airborne Measurements of Ice Nuclei

David C. Rogers, Paul J. DeMott, Sonia M. Kreidenweis, and Yalei Chen

A Combined Satellite Infrared and Passive Microwave Technique for Estimation of Small-Scale Rainfall

Martin C. Todd, Chris Kidd, Dominic Kniveton, and Tim J. Bellerby

Comparison of Precipitable Water Vapor Observations by Spaceborne Radar Interferometry and Meteosat

6.7- m Radiometry.

.. Ramon F. Hanssen, Arnout J. FeiJt, and Roland Klees

Ship-Based Sun Photometer Measurements Using Microtops Sun Photometers

John N. Porter, Mark Miller, Christophe Pietras, and Craig Motell

Enhanced Computational Methods for Nonlinear Hamiltonian Wave Dynamics. Part II: New Results JORGE F. W IILEMSEN

\section{NOTES AND CORRESPONDENCE}

On Estimating Wind Velocity Using an Upward-Looking ADCP

. George O. Marmorino and Zachariah R. Hallock

Comparisons between the TAO Buoy and NASA Scatterometer Wind Vectors

.. Suzanne Dickinson, Kathryn A. Kelly, Michael J. Caruso, and Michael J. McPhaden

Evaluation of Anomalous Propagation Echo Detection in WSR-88D Data: A Large Sample Case Study Witold F. KRajewski and Bertrand Vignal 